\title{
Praktek Jual Beli Gharar dan Pengaruhnya Terhadap Masyarakat Desa Kayumoyondi Kecamatan Kotabunan
}

\author{
Oleh: Misra Madjid
}

\begin{abstract}
ABSTRAK
Tulisan ini adalah sebuah karya ilmiah dengan metode studi penelitian lapangan yang berjudul Praktek Jual Beli Gharar dan pengaruhnya Terhadap Masyarakat Desa Kayumoyondi, Kecamatan Kotabunan, Kabupaten Bolaang Mongondow. Adapun pembahasan tentang skripsi ini adalah bagaimana praktek jual beli gharar yang ada di Desa Kayumoyondi dan pengaruhnya terhadap masyarakat Desa Kayumoyondi Kecamatan Kotabunan Kabupaten Bolaang Mongondow.

Dimana pada saat sekarang ini praktek jual beli gharar masih banyak yang harus diperhatikan terutama tentang jual beli Gharar yang ada di Desa Kayumoyondi. Dimana dalam syariat Islam jual beli seperti ini dilarang, dan dalam menentukan jual beli gharar masih terjadi silang pendapat dalam kalangan ulama.

Maka dari itu dalam skripsi ini penulis mencoba untuk mengangkat permasalahan tentang praktek jual beli gharar yang ada di Desa Kayumoyondi Kecamatan Kotabunan Kabupaten Bolaang Mongondow.
\end{abstract}




\section{PENDAHULUAN}

Agama Islam tidak hanya mengatur masalah ibadah, akan tetapi Islam juga mengatur masalah muamalah, baik yang berhubungan dengan masalah social, budaya maupun ekonomi. Adapun Islam mengatur hukum ekonomi itu sendiri mempunyai tujuan-tujuan tertentu, dan salah satunya agar orang yang berkecimpung dalam dunia bisnis dimana mereka sebagai pelak ekonomi, mempunyai etika ekonomi yang Islami atau etika yang sesuai dengan hukum Islam.

Salah satu bentuk muamalah itu adalah transaksi jual beli, sedangkan dalam Islam dasar hukum jual beli itu adalah halal, sebagaimna firman Allah SWT. Dalam surah Al-Baqarah (2) ayat 275

Terjemahannya:

"Dan Allah telah menghalalkan jual beli dan mengharamkan riba". (AlBaqarah:275) ${ }^{1}$

Akan tetapi hukum ini bisa saja berubah karena adanya suatu illat, seperti larangan jual beli yang padanya mengadung kesamaran.

Dan kesamaran pada barang yang dijual dari bentuk ketidaktahuan ada beberapa segi yaitu:

1. Dari ketidaktahuan terhadap barang yang diadakan atau penentuan akad itu sendiri.

2. Dari segi ketidaktahuan terhadap keadaan harga atau terhadap masa pembayaran harga jika disana ada masanya.

3. Dari segi ketidaktahuan tentang wujudnya harga, atau ketidakmungkinan menguasainya,

4. Dari segi ketidaktahuan tentang keselamatan harga, yakni kelangsungannya. ${ }^{2}$

Dalam hal jual beli gharar ini para ulama berbeda pendapat dalam menentukan hukumnya, ada yang melarang dan ada yang membolehkan dengan illat mereka masing-masing, karena dalam menentukan hukum sesuatu persoalan, para

\footnotetext{
${ }^{1}$ Departemen Agama RI, al Q ur'an dan Terjemahannya (Jakarta: Intermasa, 1993), h. 69.
}

${ }^{2}$ Ibnu Rusyd, Terjemahan Bidayatul Mujtahid Jilid III (Semarang:as Syifah, 1990), h. 47. 
ulamapun selalu menekankan bahwa ketentuan hukum tentang sesuatu masalah yang berkaitan erat dengan illat hukum, sehingga dikatakan bahwa adanya hukum itu ditentukan oleh atau tidak adanya illat. $^{3}$

Dalam praktek jual beli pada masyarakat Desa Kayumoyondi adalah salah satu praktek jual beli gharar, dan hal ini sangat mempengaruhi kehidupan masyarakat itu sendiri, baik kehidupan social kemasyarakatan maupun kehidupan ekonomi. Tentang permasalahan ini, mengiangat mata pencaharian masyarakat Desa Kayumoyondi sebagian besar adalah petani,

Yang terjadi pendapat di kalangan ulama adalah penjualan buah yang belum Nampak kebaikannya ataupun yang belum matang, sedangkan perselisihan di kalangan para ulama tentang menjual buah pada tangkainya terdiri dari dua hal, yaitu: menjual buah di tangkainya tanpa menyertaikan tangkainya, dan menjual buah di tangkai bersamaan dengan bijinya.

${ }^{3}$ Nurdiana Kyai Demak, Skripsi: Praktek Pinjam Meminjam Uang, manado 2001, h. 3. 


\section{LANDASAN TEORITIS TENTANG JUAL BELI GHARAR}

\section{A. Pengertian Jual Beli Dan Hal-Hal Yang Bersangkutan Dengannya}

Perkataan jual beli sebenarnya terdiri dari dua suku kata yaitu "jual dan beli". Sebenarnya kata "jual dan beli "mempunyai arti satu sama lainnya bertolak belakang.

Kata jual menunjukan bahwa adanya perbuatan menjual, sedangkan beli adalah perbuatan membeli.

Menurut pengertian syariat, yang dimaksud dengan jual beli, adalah: "pertukaran harta atas dasar saling rela. Atau: memindahkan milik dengan ganti yang dapat dibenarkan (yaitu berupa alat tukar yang sah). ${ }^{4}$

Dalam kamus Bahasa Indonesia, jual beli mmpunyai beberapa arti sebagai berikut:

1. Persetujuan saling mengikat antar penjual yakni pihak yang menyerahkan barang dan penjual sebagai pihak yang membayar harga barang yang dijual.

2. Pemberian sesuatu karena ada pembelian (imbalan yang tertentu) dengan adanya persetujuan kedua belah pihak yang didasarkan atas syarat-syarat tertentu. ${ }^{5}$

Adapun dasar hukum jual beli itu adalah sebagaimana firman Allah swt dalam Q.S. An-Nisa (4) ayat 29 :

Terjemahan:

"Hai orang-orang yang beriman janganlah kamu saling memakan harta sesame dengan jalan yang bathil, kecuali dengan jalan perniagaan yang berlaku dengan suka sama suka diantara kamu" . (Q.S. An-Nisa: 29). ${ }^{6}$

Ayat di atas dengan jelas menerangkan halalnya jual beli, tetapi disamping itu, ayat diatas juga memberikan batasan-batasan dalam bermuamalah, seperti hanya jual beli, yaitu Islam melarang adanya unsure-unsur riba' dan memakan harta sesamanya secara bathil, kemudian Islam menganjurkan agar manusia

${ }^{4}$ Chairuman Pasaribu, Hukum Perjanjian dalam Islam, (Cet. I, Jakarta: Sinar Grafika, 1994), h. 33 .

${ }^{5}$ W.J.S. Poerwadarminta, Kamus Bahasa Indonesia, (Jakarta: Balai Pustaka,1985)

${ }^{6}$ Departemen Agama: Al-Q ur'an dan terjemahan (Jakarta: Intermasa,1993),h. 122. 
menghindarkan diri dari pertengkaran dan perselisihan dalam masalah jual beli dengan menghadirkan saksi.

Adapun rukun dan syarat jual beli serta bentuk jual beli itu sendiri sebagai berikut:

1. Rukun dan Syarat jual beli

Jual beli mempunyai rukun dan syarat-syarat yang harus dipenuhi, namun dalam menentukan rukun jual beli ini terdapat perbedaan pendapat ulama. Menurut ulama Hanafiyah rukun jual beli itu hanya satu, yaitu Ijab (ungkapan membel dari pembeli) dan Qabul (ungkapan menjual dari penjual).

Menurut mereka yang mnjadi rukun dalan jual beli hanyalah kerelaan (rida'/taradhi) kedua belah pihak untuk melakukan transaksi jual beli. Akan tetapi karena unsure kereaan merupakan unsure hati yang sulit untuk diindra sehingga tidak kelihatan, maka diperlukan transaksi yang menunjukan kerelaan kedua belah pihak yang meakukan transaksi jual beli, menurut mereka, boleh tergambar oleh Ijab dan Qabul, atau melalui cara saling memberikan barang (ta'ati). Sedangkan menurut jumhur ulama menyatakan rukun jual beli itu ada empat yaitu:

a. Ada orang yang berakad atau Al-muta' qidain (penjual) dan pembeli.

b. Ada shigat (lafal Ijab dan Qabul)

c. Ada barang yang dibeli.

d. Ada nilai tukar pengganti barang ${ }^{7}$

Menurut ulama Hanafiyah, orang yang berakad, barang-barang yang dibeli dan nilai tukar barang termasuk ke dalam syarat-syarat jual beli, bukan rukun jual beli,.

Adapun syarat-syarat jual beli yang harus dipenuhi yaitu:

a. Tentang Subjeknya

Kedua belah pihak yang melakukan perjanjian jual beli haruslah:

1. Berakal, agar dia tidak terkecoh, orang gila atau bodoh tidak sah jual belinya. 135.

${ }^{7}$ Suhrawardi K. Lubis, Hukum Ekonomi Islam (Cet. II Jakarta; Sinar Grafika, 2000), h. 130- 
2. Dengan kehenak sendiri (bukan dipaksa)

3. Keduanya tidak mubazir

4. Balig

b. Tentang Objeknya

Benda yang dijadikan sebagai objek jual beli ini haruslah memenuhi syaratsyarat sebagai berikut:

1. Bersih barangnya

2. Dapat dimanfaatkan

3. Memiliki orang yang melakukan akad

4. Mampu menyerahkan

5. Mengetahui (hitungan, ukuran, timbangan atau kwalitasnya dan tentang jumlah pembayaran maupun jangka waktu pembayaran

6. Barang yang diakadkan sedang berada di tangan.

Adapun syarat-syarat Ijab dan Qabul menurut kesepakatan ulama, yaitu:

a. Keadaan Ijab dan Qabul berhubungan

b. Adanya kemufakatan keduanya walaupun lafadz keduanya belainan.

c. Keadaan keduanya tidak sangkut pautkan dengan urusan yang lain seperti: kalu saya jadi pergi saya jual barang ini sekalian.

d. Waktunya tidak dibatasi. ${ }^{8}$

Sehubungan dengan pendapat ulama Hanafiyah tentang bentuk-bentuk jual beli ini, berbeda dengan pendapat jumhur ulama, yang mana mereka tidak membedakan antara Fasid dan Batal. Dengan kata lain menurut jumhur ulama, hukum jual beli terbagi dua, yaitu jual beli sahih dan jual beli Fasid.

${ }^{8}$ Sudarsono, Pokok-Pokok Hukum Islam (Cet.I;Jakarta: Rineka Cipta,1992), h. 401. 


\section{B. Pengertian Jual Beli Gharar}

Persoalan muamalah merupakan persoalan yang senantiasa actual di tengahtengah masyarakat, karena ia berkembang sesuai dengan peradaban perkembangan umat manusia itu sendiri diantaranya persoalan jual beli.

Pengertian jual beli gharar itu terdapat berbagai beberapa macam penafsiran dari para ulama ataupun dari para ahli bahasa, diantaranya adalah, pegertian jual beli gharar menurut bahasa adalah samara tau tidak jelas, menurut istilah adalah jual beli yang belum tentu harganya, rupanya, waktunya, dan tempatnya ${ }^{9}$ sedangkan menurut pengertian lain adalah jual beli yang mengandung jalan (jalan kemiskinan) atau Mukhatara (spekulasi) atau qumaar (permainan tuduhan). ${ }^{10}$

\section{Gharar dalam Pandangan Ulama.}

Gharar yang dilarang secara umum menurut Ibnu Ja'I Maliki, yaitu:

a. Tidak dapat diserahterimakan, seperti menjual anak hewan yang masih dalam kandungan induknya.

b. Tidak diketahui harga dan barang

c. Tidak diketahui sifat barang atau harga

d. Tidak diketahui ukuran barang dan harga

e. Tidak diketahui masa yang akan datang

f. Menghargakan dua kali pada suatu barang

g. Menjual barang yang diharapkan selamat

h. Jual beli usaha, misalnya pembeli memegang tongkat jika tongkat jatuh wajib membeli

i. Jual beli munabadzah, yaitu jual beli dengan cara lempar-meempar

j. Jual beli mulamasah, apabila mengusap baju atau kain maka wajib membelinya. ${ }^{11}$

${ }^{9}$ Peter salim dan Yeni Salim, Kamus Bahasa Indonesia Kontemprorer (Jakarta:Moderen Engglis Pres, 1999), h. 226.

${ }^{10}$ Sayyid Sabiq, Fiqih Sunah (Cet. XII; Bandung: Al-Ma'arif, 1980), h. 70.

${ }^{11}$ Rachmad Syafe'I Op. Cit. h. 98. 
Disini ada beberapa macam jua beli yang menghimpun kebanyakan perkaraperkara tersebut dan sebagainya. Diantara jual beli yang megandung berbagai macam kesamaran ialah jual beli yang diperkatakan, dan jual beli yang didiamkan oleh syara'.

Akan halnya jual beli yang dperkatakan, maka kebanyakan telah disepakati, dan hanya ada perselisiahan berkenaan dengan penjelasan tentang nama-namanya. Sedang jual beli yang didiamkan masih diperselisihkan.

Objek jual beli gharar khususnya hasil pertanian

1. Jual beli yang diperkatakan,

a. Menjual buah-buahan sebelum terjadi

Menjua buah-buahan sebelum terjadi, para ulama sepakat melarangnya karena termasuk dalam larangan menjual sesuatu yang belum jadi.

b. Menjual buah-buahan sesudah terjadi

Menjual buah-buahan setelah terjadi adalah menjual buah-buahan yang telah matang walaupun masih berada di pohonya atau belum dipetik. Sedangkan menjual buah-buahan yang masih dipohon ini terbagi lagi dalam dua bagian yaitu: menjual buah-buahan yang sudah Nampak kebaikannya dan menjual buah yang belum Nampak kebaikannya.

Penjualannya yang Nampak kebaikannya atau yang sudah matang, para ulama membolehkan dengan syarat dipetik, hal ini sedikit berbeda dengan pendapat Abu Hanifah walaupun sama-sama membolehkan menjual buah yang sudah matang. Namun beliau juga membolehkan menjual buah yang telah dipetik walaupun belum matang, maksudnya buah yang belum matang tersebut telah dipetik langsung menjadi tanggung jawab pembeli.

Dan Imam Syafi'I membolehkan menjual buah-buahan yang telah matang, mengenai jual beli buah yang belum ranum, Syafi'I tidak membolehkan sesuadah terjadi atau yang telah matang. 
Jika dilihat dari penjelasan di atas yang menjadi perbedaan pendapat di kalangan ulama adalah penjual buah yang belum Nampak kebaikannya, adapun yang belum matang dan yang sudah matang serta menjual buah yang sudah bercahaya telah ranum dengan buah yang belum ranum.

Adapun ulama yang membolehkannya tetapi denga syarat sudah dipetik, menurut pandang penulis karena ada juga buah yang dapat dimanfaatkan dua keadaan, pada saat masak dan pada saat masih hijau, misalnya buah papaya, pada saat masak bisa dimakan sebagai makanan penutup dan pada saat masih hijau dapat dibuat sayur

2. Menjual buah pada tangkainya

Menjual buah pada tangkainya, maksudnya buah yang belum dikeluarkarkan dari tangkainya, seperti gandum, jenis kacang-kacangan atau bncis dan padi, dalam hal ini imam syafii berpendapat, bahwa menjual tangkai itu sendiri itu tidak boleh, meski sudah keras, karena penjualan tersebut masuk dalam bab gharar (kesamaran), dan dikiaskan pada menjual biji yang dicampurkan dengan jerami setelah digiling.

Lain halnya dengan pendapat berikut dalam hal jual tangkai itu sendiri bersama bijinya dimana Imam Malik, Imam Hanifah membolehkannya walaupun ada ulama yang megkategorikan jual beli seperti itu termasuk gharar.

Mengenai menjual buah yang semestinya masih berada di tangkainya atau belum waktunya dipetik dan ketika menjual tidak disertai dengan tangkainya, dalam hal ini Abu Hanifah dan para ulama lainnya sepakat tidak membolehkannya, seperti menjual sesuatu yang belum diketahui kualitas dan kuantitas barangnya.

Akan halnya penjualan tangkai yang sudah digosok tetapi belum kuat, maka Imam Malik tidak membolehkannya, dengan syarat dipotong dan penjual tangkai tanpa dipetik, Imam Malik merepukan tentang kebolehannya 
dan ketidak bolehannya kecuali jika berada dalam ikatannya. Adapun tentan kebolehan menjual tangkai sesudah menjadi baik, diperselisihkan pula tentang siapa yang harus mengetam dan menggilingnya. Para Fuqaha kufah berpendapat kewajiaban itu atas si penjual, diproses menjadi biji untuk si penjual. Menurut fuqaha lainnya atas si pembeli.

Jika dilihat dari uraian di atas, maka dapat dikatakan bahwa silang pendapat ini adalah berkenaan dengan hadits Nabi saw.

3. Jual beli yang didiamkan

a. Jual beli barang yang tidak ada

b. Jual beli dengan penyerahan kemudian

c. Jual beli buah-buahan dalam satu atau beberapa lembah. ${ }^{12}$

Dalam hal jual beli barang yang tidak ada dan jual beli buahbuahan dalam satu atau beberapa lembah, yang menjadi silang pendapat di kalangan ulama adalah apakah kesamaran itu termasuk kesamaran besar ataukah kesamaran keci (ringan) yang dimaafkan. Sedangkan dalam hal jual beli dengan penyerahan kemudian, yang menjadi silang pendapat di kalangan ulama adalah pada syarat penyerahan barang, selain itu silang pendapat ini pada hal pandanganhutang dengan hutang.

\footnotetext{
${ }^{12}$ Ibnu Rusyd, Op Cit. h. 64-67.
} 


\section{ANALISIS JUAL BELI GHARAR DI DESA KAYUMOYONDI}

\section{A. Pelaksanaan Jual Beli Gharar di Desa Kayumoyondi}

Di sadari bahwa manusia sebagai subjek hukum tidak mungkin hidup di ala mini sendiri saja, tanpa berhubungan sama sekali dengan manusia lainnya. Eksistensi manusia sebagai makhluk social sudah merupakan fitrah yang ditetapkan Allah bagi mereka. Suatu hal yang paling mendasar dalam memenuhi kebutuhan seorang manusia adalah adanya interaksi social dengan manusia lain.

Kehidupan manusia di atas dunia tentu tidak dapat dipisahkan dengan ingin memenuhi kebutuhan hidup, baik sandang, papan maupun pangan, disamping itu pula untuk memenuhi kebutuhan tersebut, diharapkan agar manusia berusaha dengan berbagai cara agar kebutuhan tersebut dapat terpenuhi dengan memperhatikan kaidah-kaidah yang telah diatur dalam Islam.

Dalam kehidupan bermasyarakat untuk melanjutkan kehidupannya maka manusia sering mengalami kekurangan maupun kelebihan. Dari keadaan yang demikian inilah manusia yag mengalami kekurangan memerlukan bantuan dan pertolongan orang lain, di saat-saat seperti inilah maka dari sisi mulainya manusia tidak dapat melepaskan diri dariperbuatan Muamalah, seperti transaksi jual beli, pinjam meminjam dan lain sebagainya. Dalam hal ini, Islam telah memberikan suatu batasan bahwa perbuatan jual beli, pinjam meminjam, maupun tolong menolong hendaknya sesuai dengan ajaran Islam.

Namun tidak dapat dipungkiri bahwa sering karena kebutuhan ekonomi, orang sering melakukan hal-hal atau usaha-usaha yang tidak sesuai dengan syariat Islam, apakah hal itu sengaja dilakukan karena tuntutan kebutuhan atau karena ketidaktahuan akan hukum yang mengatur hal itu, dalam hal ini hukum tentang muamalah khususnya hukum tentang jual beli. Seperti yang terjadi pada masyarakat Desa Kayumoyondi dalam praktek jual beli yang disebut dengan jual beli gharar.

Adapun praktek jual beli gharar di desa Kayomoyondi sebagaimana yang diterangkan oleh Ibn Muliana sebagai berikut: "Dimana penjual datang kepada 
pembeli dengan menawarkan sejumlah barang dalam hal ini cengkih atau kelapa tetapi barang yang akan dijual tidak di bawah dengan kata lain masih berupa perjanjian yang nanti akan diserahkan oleh penjual pada saat panen, dan ini kami sebut denga hijau,ada juga yang kami sebut dengan sewa pohon, dimana pembeli akan memetik setelah masa sewa panen telah tiba, setelah melalui musyawarah dan jual beli ini disetujui oleh kedua pihak, baik dari harga maupun waktunya, maka pembeli menyerahkan uang untuk pembayaran barang yang dimaksud. ${ }^{13}$

Jika dilihat dari penjelasan di atas dikemukakan pendapat bahwa jual beli yang seperti ini adalah termasuk bentuk jual beli gharar karena dalam hal ini mereka bersekulasi harga dan barang.

"Kami sebagai penjual kadang mengalami kerugian tetapi kami berfikir bahwa kemungkinan untung atau rugi itu adalah sudah merupakan resiko bagi kami, naun ada juga pembeli yang apabila merasa telah memperoleh keuntungan yang lebih, maka mereka akan memberikan persenan tanpa diminta oleh kami. ${ }^{14}$

Dilanjutkan dengan ungkapan lain bahwa ada juga orang yang walaupun mendapatkan keuntungan yang lebih merasa tidak akan memberikan persenan kepada penjual, karena menurut mereka itu merupakan keuntungan bagi mereka, dan penjual tidak boleh menuntutnya. ${ }^{15}$

Dengan hasil wawancara dengan beberapa reponden di atas, maka dapatlah dilihat bagaimana praktek jual beli gharar yang dilaksanakan masyarakat Kayumoyondi serta dampak yang ditimbulkannya baik bagi penjual maupun pembeli, dimana akibat dari system penjualan yang tidak sesuai dengan syariat Islam, akhirnya menimbulkan hal-hal yang kadang merugikan pihak-pihak itu sendiri, baik yang disebabkan oleh hasil buah itu sendiri aupun yag disebkan oelh subjek itu sendiri.

\footnotetext{
${ }^{13}$ Hasil Wawancara dengan Muliana pembeli, tanggal 24 Agustus 2003, di desa Kayumoyondi.

${ }^{14}$ Hasil Wawancara dengan Rusli, Penjual, tanggal 26 Agustus 2003, di desa Kayumoyondi.

${ }^{15}$ Hasil Wawancara dengan Muksin, juru Tulis, tanggal 14 September 2003, di desa Kayumoyondi.
} 
Kemudian dari hasil penjelasan yang penulis peroleh pula ternyata masih banyak masyarakat yang melakukan transaksi jual beli tanpa membuat surat jual beli, disini yang penting bagi mereka hanyalah jual beli, disini yang penting bagi mereka hanyalah kepercayaan dan kejujuran, tetapi jika dikaji ebih jauh lagi bahwa, sebenarnya Islam telah memberikan ataran atau kemashlahatan manusia itu sendiri. Dan salah tujuannya untuk meghindari sengketa kemudian hari, masalah ini yang diungkapkan oleh Bapak Sangadi bahwa:

"Terkadang ada pihak-pihak yang karena jual beli yang dilakukan secara tidak tunai itu, tidak ada bukti yang tertulis akhirnya ketika timbul sengketa, masingmasing pihak yang bersengketa tidak ada bukti untuk menguatkan dari masingmasing pihak. ${ }^{16}$

Dalam masalah hukum muamalah terutama dalam hal jual beli khususnya jual beli gharar atau yang mereka sebut dengan ijon ini sebenarnya sudah ada yang mengetahui akan larangannya, tetapi karena kebutuhan ekonomi mendesak terpaksa mereka harus melakukan hal ini untuk memenuhi kebutuhan mereka, sebagaimana yang diungkapkan oelh ibu Jama

“sebenarnya saya pernah mendengar bahwa jual beli ijon (gharar) iu dilarang, akan tetap karena kebutuhan yang mendesak, maka terpaksa saya tempuh jalan ini, sebab kalau menurut saya uang seratus ribu untuk waktu sekarang sangat saya butuhkan masih lebih berharga dari pada satu juta untuk waktu yang akan datang. Dan jual beli seperti ini kami lakukan atas dasar suka sama suka". ${ }^{17}$

Melihat masalah di atas, menurut analisa penulis masih perlu adanya bimbingan-bimbingan bagi masyarakat, dalam berusaha, agar jual beli gharar ini tidak akan menjadi kebiasaan yang berlaru-larut, seperti yang diungkapkan oleh para tokoh masyarakat berikut ini, bahwa:

\footnotetext{
${ }^{16}$ Hasil Wawancara dengan Kisman, Sangadi, tanggal 15 September 2003, di Desa Kayumoyondi.

${ }^{17}$ Hasil wawancara dengan Djamal, penjual, pada tanggal 30 Agustus 2003, di Desa Kayumoyondi.
} 
“dalam masalah ini ada masyarakat yang sudah mengetahui dan ada juga yang belum, untuk itu masih tetap dierlukan adanya bimbingan dan arahan, seperti melalui dakwah atau buku-buku bacaan, agar hal ini tidak menjadi kebiasaan yang berlarutlarut, disamping itu perlu adanya lembaga pemerintahan seperti koperasi tani dan lain-lain agar kebutuhan masyarakat dapat terpenuhi dengan cara yang lebih baik tanpa ada masalah di kemudian hari yang dapat menmbulkan retaknya hubungan baik antara masyarakat".

"Saya sebagai pembeli bahkan ada penjual ang sudah menjadi langganan saya. Dahulu saya belum mengetahui tentang hukum ini, setelah mendengar informasi yang ada bahwa jual beli seperti ini adalah dilarang, akhirnya saya berusaha menghindarinya,tetapi masih ada juga para petani yang datang untuk menjual hasil kebun mereka dengan cara seperti ini, mereka datang dengan berbagai keluhan, seperti mereka butuh biaya untuk keluarganya yang sakit, biaya sekolah dan lain-lain, akhirnya saya terpaksa membelinya karena terdorong rasa ingin menolong." 18

Adapun dari keterangan lain yang penulis peroleh bahwa "ada juga orang yang hanya karena factor malas", ${ }^{19}$ factor ingin berfoya-foya, untuk kebutuhan yang tidak terlalu penting, akhirnya mereka tempuh cara ini yang seakan-akan jual beli seperti ini sudh menjadi kebiasaan mereka. Jadi sebenarnya salah satu cara yang harus ditempuh untuk menghindari hal ini adalah ditanamkan pola hidup sederhana dalam kehidupan masyarakat. Agar tidak terlalu terlena dengan jual beli seperti ini. ${ }^{20}$

Berdasarkan hasil wawancara di atas, menurut analisa penulis bahwa pembeli melakukan jual beli seperti ini, karena terdorong oleh rasa ingin menolong, disamping itu dalam hal ini mereka sebagai pembeli untuk dapat lebih mengembangkan usaha mereka tentunya factor untuk mendapat keuntungan itu

\footnotetext{
${ }^{18}$ Hasil wawancara dengan Ibu Aeda, Pembeli, pada tanggal 10 September 2003, di Desa Kayumoyondi.

${ }^{19}$ Hasil wawancara dengan Ismail, Tokoh Masyarakat, pada tanggal 14 September 2003, di desa Kayumoyondi.

${ }^{20}$ Hasil wawancara dengan Usman, Tokoh Masyarakat, pada tanggal 15 September 2003, di desa kayumoyondi.
} 
mereka harapkan, sebagaimana yang dikatakan oleh seorang bapak, bahwa : "saya sebagai pembeli, dimana jual beli sudah merupakan salah satu usaha dalam memenuhi kebutuhan kami disamping ada rasa ingin menolong, tentunya tidak lepas juga dari ingin mendapatkan keuntungan".

Jika dilihat dari keterangan diatas penulis menganalisa bahwa usaha jual beli itu adalah dibolehkan (halal), dan factor untuk mendapatkan keuntungan itu adalah hal yang wajar, dan sejalan dengan motif ekonomi: yaitu dorongan-dorongan yang mucul dalam diri seseorang untuk melakukan tindakan ekonomi dalam usaha memperoleh keuntungan, memenuhi kebutuhan, dan mencapai kemakmuran dalam kehidupannya.

\section{B. Pengaruh pelaksanaan jual beli gharar terhadap masyarakat Desa Kayumoyondi}

Dari hasil wawancara yang ada, penulis dapat menganalisa bahwa jual beli gharar ini ternyata telah menjadi suatu kebiasaan masyarakat Desa Kayumoyondi dalam memenuhi kebutuhan mereka. Dan hal ini sangat berpengaruh terhadap kehidupan mereka, baik bagi pembeli dan penjual khususnya maupun masyarakat pada umumnya.

Dari hasil wawancara pada pembahasan sebelumnya dapat penulis analisa bahwa secara tidak langsung maupun langsung terjadi tolong menolongantara si penjual dan si pembeli, karena kebutuhannya terpenuhi oleh si pembeli, karena kebutuhannya terpenuhi oleh si pembeli, dan si pembeli akan mendapatkan keuntungan dari jual beli tersebut. 


\section{Pandangan Ulama Terhadap Praktek Jual beli gharar di Desa Kayumoyondi}

Larangan syar'i akan jual beli gharar ini sebagaimana telah dijelaskan dalam hadits-hadits Nabi saw, dan telah dibahas pada bab sebelumnya. Akan tetapi dala menentukan hal-hal yang termasuk jual beli gharar yang dilarang, dalam pandangan ulama masih terdapat pebedaan pandangan.

\section{PENUTUP}

\section{A. Kesimpulan}

Praktek jual beli gharar dan pengaruhnya terhadap masyarakat Desa Kayumoyondi kecamatan kotabunan

1. Praktek jual beli gharar pada masyarakat Desa Kayumoyondi yaitu dengan cara pembayaran didahulukan walaupun harga dan barangnya belum jelas atau belum dilihat, dimana mereka hanya berspekulasi, dan hal ini adalah termasuk jual beli ghrar.

2. Dari pelaksanaan jual beli gharar ini sangat mempengaruhi kehidupan masyarakat Kayumoyondi, baik terhadap kehidupan social kemasyarakatan maupun ekonomi, ada yang bersifat positif, yaitu terpenuhinya kebutuhan si penjual oleh si pembeli, dan ada yang bersifat negative, namun pengaruh negatifnya masih lebih besar, yaitu retaknya hubungan antara sesame manusia, putusnya hubungan silaturrahmi dengan rasa persaudaraan yang pada akhirnya dapat mengganggu keamanan dengan ketentraman kehidupan masyarakat.

\section{B. Saran-Saran}

Kepada seluruh masyarakat khusya umat Islam, penulis menyarankan agar dalam pelaksanaan jual beli sebagai bentuk muamalah dalam masyarakat yang merupakan kebutuhan hidup manusia, hendaknya mengikuti petunjuk sesuai dengan syariat Islam yang membolehkan jual beli, dan melarang jual beli yang mengandung 
gharar dan mengambil keuntungan yang berlebih-lebihan yang membuat kita terjebak dalam perbuatan riba, dan memakan harta orang lain secara bathil.

\section{DAFTAR PUSTAKA}

Al Hasby Husin, Kamus Besar Kautsar Lengka Arab-Indonesia, Cet. III, Bangil, Yayasan Pasantren Islam, 1986.

Arifin Bey, et. al., Terjemah Sunan Abi Daud, Cet. I, Semarang: Asy-Syifa',1993

As'ad Aliy :F athul Mu'in, Jilid II, Menara Kudus, Yogyakarta: 1979

Departemen Agama: Al-Qur'an Dan Terjemahan, Edisi Baru 1989,

Pasaribu Charuman, Hukum Perjanjian Dalam Islam, Cet. I, Jakarta: Sinar Grafika, 1994

Haroen Nasrun, Fiqih Muamalah, Cet. I, Jakarta, Gaya Media Pratama, 2000

Lubis Suhrawandi K., Hukum Ekonomi Islam, Cet. II, Jakarta: Sinar Grafika, 2000

Salim Peter Dan Heni Salim, Kamus Bahasa Indonesia Kontemporer, Jakarta: Modern Engglis Pres, 1997 